\title{
Ellipsis
}

2014

\section{Paper Trail}

John Wolfe

University of New Orleans

Follow this and additional works at: https://scholarworks.uno.edu/ellipsis

Part of the Poetry Commons

\section{Recommended Citation}

Wolfe, John (2014) "Paper Trail," Ellipsis: Vol. 41 , Article 6.

DOI: https://doi.org/10.46428/ejail.41.06

Available at: https://scholarworks.uno.edu/ellipsis/vol41/iss1/6

This Poetry is brought to you for free and open access by the Department of English and Foreign Languages at ScholarWorks@UNO. It has been accepted for inclusion in Ellipsis by an authorized editor of ScholarWorks@UNO. For more information, please contact scholarworks@uno.edu. 


\section{Paper Trail}

John Wolfe

It's not only the word rave hiding inside intravenous or the lie That some of his informal schooling happened abroad, but also His winter internship inhaling vog in Hawaii should be weighed.

It's a precarious universe, man. Forever an umbilical cord

Too thick to snip. He's certain if he'd received a dose Of Homer instead of Homer Simpson at conception, Stuff might have been different, but it's not too late To return to school forever. His father kept pointing

Outside the walls without windows. Home is where the heart Collects dust, his mother demonstrated. She said if you're smart You'll split, so when all the papers were in order, signatures legible, He made up addresses for how he'd be reachable,

Opened the front door, stepped into a cross-breeze, And waved down the first thing with wheels. 